mgr inz. Tomasz Antkowiak

mgr inz. Zdzislaw Pawlak

Instytut Pojazdów Szynowych"TABOR"

\title{
Diagnostyka techniczna układu biegowego trakcyjnego pojazdu szynowego
}

\begin{abstract}
$W$ artykule przedstawiono zagadnienia zwiqzane ze stosowanq diagnostyka taboru kolejowego oraz problemy do rozwiqzania $w$ tym zakresie dla pojazdów modernizowanych $i$ nowobudowanych. Artykul powstat $w$ ramach projektów celowych: „Prognozowanie stanu technicznego głównych systemów pojazdu szynowego na podstawie analizy zmian wartości charakterystycznych parametrów podzespolów” N N509 336637 i „Mikroprocesorowy system diagnostyczny głównych systemów trakcyjnego pojazdu szynowego uwzględniajacy ocene bieżaca i prognozowanie stanów” N R10 0048 06/2009 finansowanych przez Ministerstwo Nauki i Szkolnictwa Wyższego.
\end{abstract}

\section{Wstęp}

Zadaniem diagnostyki technicznej w systemach obsługi pojazdów szynowych jest umożliwienie określenia aktualnego stanu technicznego pojazdów i realizowanie $\mathrm{w}$ zależności od aktualnego stanu technicznego odpowiedniego zakresu obsługi oraz prognozowanie dalszego niezawodnego użytkowania.

Stan techniczny pojazdu określa struktura pojazdu, a parametry tej struktury sa parametrami stanu technicznego tj. parametrami diagnostycznymi.

Badania diagnostyczne pozwalają określić aktualny stan obiektu technicznego $\mathrm{z}$ reguły bez demontażu tego obiektu lub podczas częściowego jego demonta- 
żu, nie naruszającego jednak zasadniczego elementu. Wymaga to jednak znajomości wzajemnych związków parametrów struktury i parametrów wyjściowych.

Układ biegowy trakcyjnego pojazdu szynowego jest złożonym urządzeniem technicznym i w związku $\mathrm{z}$ tym trudnym obiektem diagnostycznym. Wynika to $z$ dużej liczby parametrów struktury determinujących jego stan techniczny. Dlatego zachodzi konieczność wykorzystywania odpowiedniego dużego zbioru $S$ parametrów diagnostycznych, które są parametrami charakteryzu-jącymi różnorodne procesy fizyczne i chemiczne powstające w czasie funkcjonowania pojazdu. Rozdzielając pojazd szynowy (zbiór $S$ ) na obiekty diagnostyczne tworzymy podzbiory robocze $\mathrm{i}$ towarzyszące im parametry diagnostyczne. Podział ten wynika $\mathrm{z}$ badanego obiektu i wykorzysty-wanych procesów wyjściowych. W związku z różnorodnością procesów wyjściowych, wykorzystywanych podczas diagnozowania pojazdów i ich zespołów, ścisły podział parametrów na robocze i towarzyszące jest trudny i może być niejednakowy dla poszczególnych obiektów.

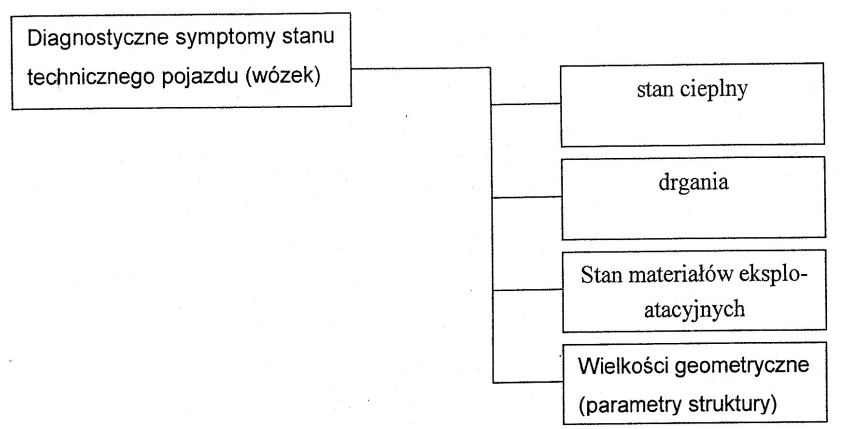

Rys. 1 Klasyfikacja symptomów diagnostycznych

Poszczególne symptomy będą opisywane różnymi wielkościami fizycznymi (parametrami) w zależności od tego, jaki obiekt charakteryzują. Stan cieplny określamy za pomocą temperatury elementów oraz jej szybkość narastania, jest wykorzystywany do oceny stanu technicznego tych zespołów. Procesy drganiowe towarzyszace pracy wszystkich ruchomych elementów pojazdów, są wykorzystywane do ogólnej oceny stanu technicznego pojazdu oraz jego zespołów, jak również do lokalizacji niesprawności. Stan materiałów eksploatacyjnych charakteryzowany np. ilością i składem zanieczyszczeń w smarze oraz zmianą jego właściwości użytkowych, umożliwi ocenę intensywności stopnia zużycia łożysk. Za pomocą wielkości geometrycznych (np. luzy) możemy diagnozować np. zużycie przekładni.

Wyróżnia się dwa sposoby wnioskowania diagnostycznego.

1 - wykorzystujące symptomy diagnostyczne (zbiór relacji: symptom-stan)

2 - wykorzystujące modele (zbiór relacji: stanparametry modelu).
Ocenę stanu technicznego pojazdu można dokonać monitorowaniem stanu „off-line” na podstawie wyników pomiarów okresowych lub „on-line” na podstawie wyników pomiarów zarejestrowanych przez system ciagłego monitoringu.

Pozwala to na określenie przebiegu zmian parametrów pojazdu w funkcji wykorzystania jego potencjału eksploatacyjnego (stan zdatności).

Pomiar wartości parametru diagnostycznego wykonujemy wybraną metodą diagnostyczną.

Zbiór parametrów diagnostycznych powinien uwzględniać [7]:

- zdolność odwzorowania zmian stanu pojazdu w czasie eksploatacji

- ilość informacji o stanie pojazdu

- odpowiednią zmienność parametrów diagnostycznych w czasie eksploatacji pojazdu

- specyfikę eksploatacji pojazdów szynowych

\section{Diagnostyka układu biegowego pojazdu szy- nowego realizowana na $P$ KP}

Realizacja badań diagnostycznych obejmuje pomiary charakterystycznych parametrów, które można wykonać podczas pracy badanego pojazdu co określamy jako diagnostykę funkcjonalną lub w czasie planowanych przeglądów. W dalszych rozważaniach pomijamy tradycyjne pomiary za pomocą przenośnych przyrządów.

\subsection{Diagnostyka zestawów kołowych 2.1.1. Automatyczne systemy detekcji stanów awa- ryjnych w taborze kolejowym}

\section{ASDEK/PMZ/GM/GH/OK./PHOENIX/GOTC HA [13]}

producent: TENS Sp. z o.o. Sopot

Jest to system stacjonarny, bezobsługowy, przeprowadzający diagnostykę $\mathrm{w}$ trakcie normalnej eksploatacji pojazdu kolejowego. Procedury pomiarowe uruchamiane sa automatycznie w chwili wjazdu pociagu w obszar bazy pomiarowej systemu.

System realizuje następujące funkcje detekcji:

- wykrywanie deformacji bieżni kół funkcja PM

- wykrywanie zagrzanych osi funkcja GM

- wykrywanie zakleszczonych hamulców funkcja $\mathrm{GH}$

- wykrywanie obciążenia toru kolejowego funkcja OK.

\subsubsection{Laserowy pomiar kót i wózków taboru [14]} producent: P.U.T GRAW Sp. z o.o. Gliwice

Jest to system stacjonarny instalowany na wjeździe do zajezdni. Przeznaczony do automatycznego bezdotykowego pomiaru geometrii wózków oraz profili i średnic kół. 
Dane pomiarowe poprzez komputer pomiarowy przesyłane są do bazy danych, która jest podstawą do planowania napraw.

\subsubsection{System wykrywania plaszczyzn i nalep kót taboru WF [14]}

producent: P.U.T GRAW Sp. z o.o. Gliwice

Jest to stacjonarny system pomiarowy wbudowany $w$ torowisko $\mathrm{w}$ pełni zautomatyzowany wraz z oprogramowaniem i daje podstawy do planowania remontów.

\subsubsection{System nadzorowania stanu kót taboru P\&D [14]}

producent: P.U.T GRAW Sp. z o.o. Gliwice

Bazy danych stanowia system do gromadzenia informacji o kontroli geometrii kół taboru kolejowego opracowany przez firmę GRAW.

System może integrować dane pomiarowe zebrane $\mathrm{z}$ przyrządów ręcznych jak i automatycznych stanowisk. Baza danych systemu pozwala na prognozowanie niezawodnej eksploatacji kół zestawów kołowych wg wybranych kryteriów.

\subsection{Diagnostyka hamulców}

2.2.1. Stanowisko diagnostyczne do kontroli $i$ oceny stanu technicznego uktadów hamulcowych elektrycznych zespotów trakcyjnych HADIAG/EZT [15]

producent: TENS Sp. z o.o. Sopot

System HADIAG posiada mechanizmy autotestowania wykrywające i sygnalizujące ewentualne niesprawności w działaniu urządzeń. Po włączeniu systemu automatycznie testowane są podzespoły cyfrowe i cyfrowo-analogowe modułów odpowiedzialnych za zbieranie i przetwarzanie danych.

$\mathrm{Na}$ bieżąco prowadzony jest monitoring stanu technicznego modułów kluczowych dla systemu: zasilania, magistrali komunikacyjnej, układu sterowania oraz czujników pomiarowych.

Jest to stanowisko stacjonarne, zautomatyzowane wraz z oprogramowaniem.

\subsection{Diagnostyka wózków}

2.3.1. Systemy do kontroli, oceny stanu technicznego i regulacji zawieszenia taboru kolejowego TENSAN [15]

producent: TENS Sp. z o.o. Sopot

System TENSAN są rodziną stacjonarnych urządzeń diagnostycznych do kontroli, oceny stanu technicznego i regulacji zawieszenia pojazdów szynowych.

Proces pomiarowy jest zautomatyzowany:

- system TENSAN/P - umożliwia pomiary i regulacje rozkładu nacisków wszystkich pojazdów szynowych oraz pomiar sztywności skrętnej na ruchomym wózku poprzez oddzielny pomiar każdego wózka

- system TENSAN/PL - umożliwia pomiary i regulację nacisków oraz pełny pomiar sztywności skrętnej wszystkich typów lokomotyw
- system TENSAN/PLW - umożliwia pomiary i regulację nacisków oraz pełny pomiar sztywności skrętnej wszystkich typów pojazdów szynowych.

\subsection{Diagnostyka pokładowa pojazdów trakcyj-} nych

producenci: ENTE Sp. z o.o. Gliwice

Instytut Elektrotechniki Warszawa

Instytut Pojazdów Szynowych „TABOR" Poznań

Diagnostyka pokładowa zostaje wprowadzona w ramach modernizacji lokomotyw np. ET22 i EM10 gdzie zostaje zrealizowany mikroprocesorowy system sterowania i diagnostyki.

W zakresie układu biegowego diagnostyka ma ograniczony zakres:

- hamulec - monitorowanie zgodności ciśnienia przewodu głównego i cylindra z zadanymi poziomami hamowania

- lożyska - pomiar temperatury

- uklad napędowy - monitorowanie danych o stanie urządzeń (obroty, prądy trakcyjne).

3. Nowe rozwiązania w zakresie diagnostyki układu biegowego wdrożone przez producentów europejskich

3.1 Zespół łożyskowania osi SKF Axletronic wyposażony $w$ zintegrowane czujniki prod. SKF [1]

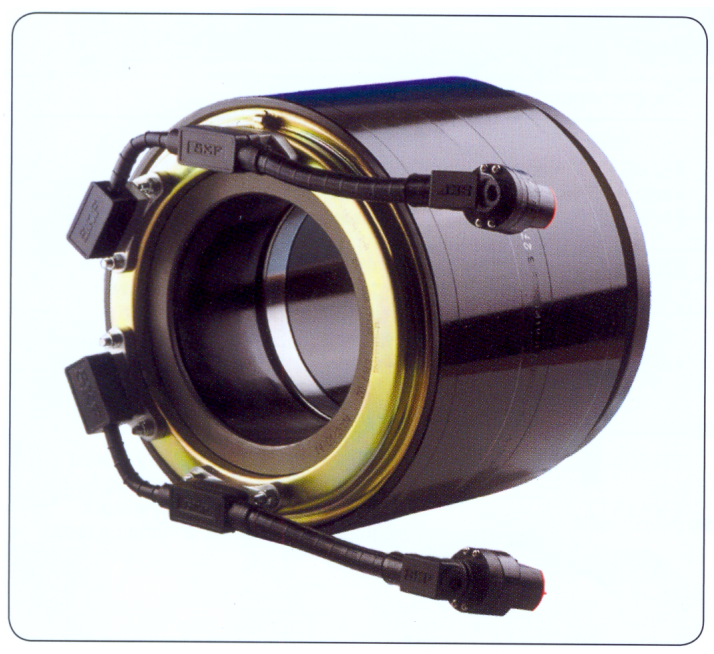

Rys. 2 - Zespół łożyskowania osi SKF Axletronic

Zespół łożysk SKF wyposażony jest w zintegrowany czujnik określający temperaturę, obroty, przyspieszenia (kierunek pionowy i poziomy) jak w łożyskach kompaktowych CTBU oraz dodatkowo czujnik lokalizujący dla ETCS.

Czujniki mierzą ogólny poziom drgań co daje nam informacje o ogólnym stanie łożysk jak też o współpracy koła z szyną gdzie następuje generowanie drgań związanych ze stanem technicznym koła zestawu i szyny. 
Analiza częstotliwościowa (widmowa) rozkłada sygnał drgań na składowe harmoniczne o różnych częstotliwościach. Wzrost poziomu składowych oraz wzrost ich częstotliwości dostarczają informacji co uległo uszkodzeniom.

Sygnały pomiarowe $\mathrm{z}$ czujnika przekazywane są do układu monitorowania wózka stanowiącego część pokładowego systemu monitorowania pojazdu.

\subsection{Pokładowy system monitorowania stanu po- jazdu - SKF Multilog On-line System IMx-R [1] \\ producent: $\quad$ SKF}

Systemy monitorowania stanu online firmy SKF zostały opracowane $\mathrm{w}$ celu ułatwienia wczesnego wykrywania uszkodzeń i zapobiegania im oraz zapewnienia automatycznego powiadamiania dla skorygowania bieżącego lub przewidywanego stanu i danych wejściowych dla systemów zarządzania obsługą uwarunkowaną stanem obiektu. System monitorowania SKF Multilog On-line System IMx-R, opracowany specjalnie dla przemysłu kolejowego, zapewnia zwiększoną niezawodność dzięki monitorowaniu, np.:

- stanu łożyskowania zestawu kołowego i trwałości użytkowej środka smarnego

- spłaszczeń i kształtu koła

- stateczności i kołysania wózka

- warunków wykolejenia

- stanu układu napędowego tj. silników trakcyjnych, przekładni i wałów napędowych

- niewyważenia i warunków powstawania rezonansu

- stanu torów.

Multilog On-line System IMx-R zapewnia automatyczne ostrzeganie, zależne od obciążenia prędkości, oraz alarmy, które inicjują łączność wewnętrzną i zewnętrzną, przetwarzanie danych dla automatycznego diagnozowania i analizy zasadniczych przyczyn problemu oraz połączenie $\mathrm{z}$ systemami zarządzania obsługą, pozwalając na planowanie i zarządzenie dostawą części zamiennych. System zapewnia dostęp użytkownikowi końcowemu do bazy danych poprzez witrynę internetową.
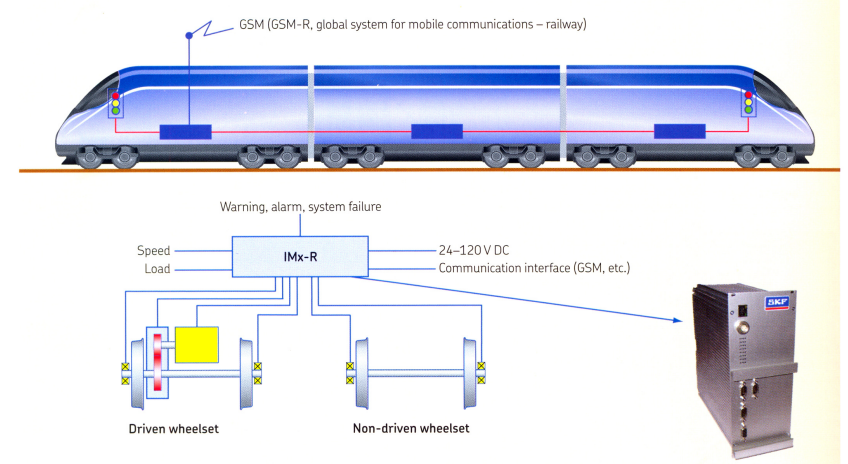

Rys. 3 - System monitorowania układu napędowego SKF Multilog on-line IMx-R

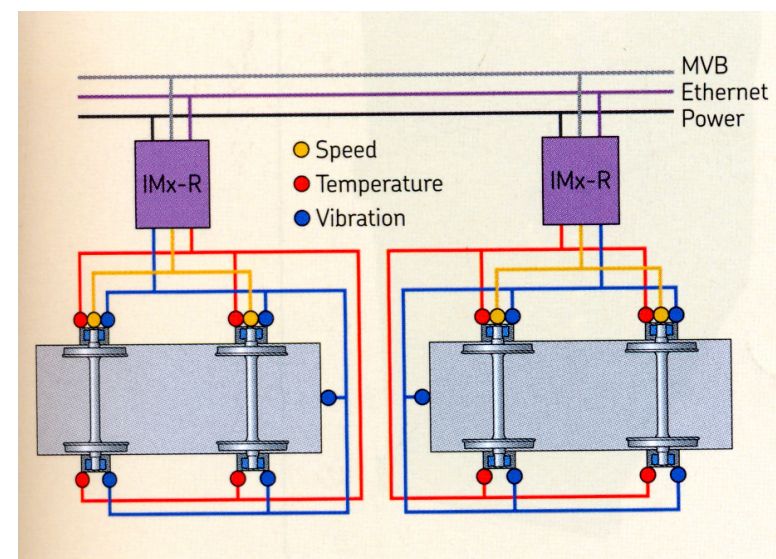

Rys. 4 - System monitorowania wózka SKF Multilog on-line IMx-R

\subsection{Monitoring wózka lok. Re 465 firmy Bombar- dier [10]}

Firmy Bombardier Transportation i SKF Condition Monitoring Center-Lulea opracowały system monitorowania wózków typu Mitrac MCM dla lokomotywy Re 465.

System ten służy do kontroli wszystkich zespołów posiadających części wirujące. $\mathrm{W}$ ten sposób mogą być wykryte i zdiagnozowane następujące stany i przypadki: stan łożysk i ich temperatura, płaskie miejsca i kształt koła, stabilność wózka i występowanie drgań wężykowania, stan wykolejenia, stan mechaniczny silnika i przekładni, problemy niewyważenia i rezonansu, stan szyn.

System MCM bazuje na analizie danych przyspieszeń i temperaturowych $\mathrm{z}$ uwzględnieniem występujących informacji jakimi są: prędkość obrotowa silnika, siła pociagowa lub usytuowanie pojazdu na linii kolejowej. Odpowiednie czujniki sensorowe umieszczone na wózku i dane otrzymane z magistrali pojazdu dostarczają niezbędnych informacji.

System Mitrac MCM rozpoznaje automatycznie częstotliwości, które są charakterystyczne dla błędów spowodowanych przez usterki. System ten posiada odpowiedni zespół algorytmów diagno-stycznych, który generuje automatycznie alarm dla maszynisty przez magistralę.

\subsection{Metoda oceny stanu wlasności dynamicznych i tras kolejowych za pomocą detekcji wykolejeń [9]}

W wyniku doświadczalnych i symulacyjnych badań niemieckich opracowano metodę mająca na celu wczesne wykrywanie pojazdów zagrożonych wykolejeniem. Stwierdzono, że istotnym elementem bezpiecznej jazdy pojazdów szynowych jest poziom drgań zestawów kołowych.

Zastosowano nową formę oceny bezpiecznej jazdy pojazdu szynowego za pomocą współczynnika $\lambda$, charakteryzującego poziom przyspieszeń zestawu kołowego i otrzymanego w wyniku dyskretnej transformacji „Karhunen-Loeve”. Jako graniczną 
wartość współczynnika $\lambda$, wyrażającego poziom energii zakłóceń podczas jazdy, uznano zakres $25 \div$ $40 \mathrm{~m}^{2} / \mathrm{s}^{4}$.

Zasada ta polega na zabudowie sensorów przyspieszeń na maźnicach, które po przedstawieniu danych, przesyłają informacje do satelity a ten do centrali informacyjnej zarządu kolejowego.

\subsection{System diagnostyczny kól kolejowych ARGUS}

[12]

producent: Hegenscheidt MFD Niemcy [12]

System diagnostyczny jest całkowicie zautomatyzowanym stacjonarnym urządzeniem kontrolnopomiarowym kół jezdnych pojazdów szynowych będących w ruchu eksploatacyjnym. W trakcie przejazdu przez moduły diagnostyczne wszystkie koła są automatycznie sprawdzone:

moduł 1: identyfiakacja pojazdu

moduł 2: kołowość, płaskie miejsce

moduł 3: średnica

moduł 4: profil, odległość między obrzeżami kół jezdnych

moduł 5: wykrywanie pęknięć.

W stosunku do innych systemów diagnostycznych nowością jest moduł wykrywania pęknięć metoda ultradźwiękową.

4. Wymagania w zakresie diagnostyki układu biegowego wg obowiązujących przepisów, norm, TSI

4.1 Ie-3 Wytyczne techniczno-eksploa-tacyjne urządzeń do wykrywania stanów awaryjnych taboru [18]

PKP PLK S.A. Warszawa 2005 r.

Instrukcja określa zakres diagnostyki dla stosowanych na PKP urządzeń detekcji stanów awaryjnych taboru $(d s a t)$ :

PM - płaskie miejsca

GM - gorące maźnice

GH - gorące obręcze (klocki hamulcowe) i

tarcze hamulcowe

OK. - obciążenie kół.

Dla poszczególnych funkcji określone są wartości progowe (ostrzegawcze i alarmowe).

Określono kategoryzację osłony infrastruktury kolejowej:

linie kat. I $\quad \mathrm{v}>200 \mathrm{~km} / \mathrm{h}$

linie kat. II $120 \mathrm{~km} / \mathrm{h}<\mathrm{v} \leq 200 \mathrm{~km} / \mathrm{h}$

Dla linii kat. I przy braku (wyłączeniu) urządzeń $d s a t$ bezwzględna jest konieczność stosowania diagnostyki pokładowej.

\subsection{Wymagania TSI - Tabor transeuropejskiego} systemu kolei dużych prędkości

Decyzja Komisji Europejskiej nr 2008/232/WE z 21.02.2008 w Dz. U. WE nr L84 z dnia 26.03.2008 [11].

- p. 4.2.7.10 Rozwiązania w zakresie monitorowania i diagnostyki
Funkcje i urządzenia określone w niniejszej TSI i powtórzone poniżej powinny być monitorowane samodzielnie lub zewnętrznie:

- $\quad$ wykrywanie niestabilności (p. 4.2.3.4.5)

- pokładowe monitorowanie stan łożysk osi (p. 4.2.3. 3.2.1)

- układ hamulcowy (p. 4.2.4.3)

- wykrywanie wykolejenia (p. 4.2.3.4.11).

Monitorowanie funkcji i urządzeń musi być wykonywane bez przerwy lub $\mathrm{z}$ częstotliwością mogącą zapewnić wykrycie usterki na czas.

W pociagach klasy 1 system ten powinien być także połączony $\mathrm{z}$ pokładowym rejestratorem danych diagnostycznych, aby umożliwić śledzenie stanu systemów.

\subsubsection{Wykrywanie niestabilności (p. 4.2.3.4.5)}

Jeżeli stateczność zależy od zastosowania urządzeń, które nie są odporne na uszkodzenia, pociagi jeżdżące z prędkościami przekraczającymi $220 \mathrm{~km} / \mathrm{h}$ muszą mieć alarm od niestateczności zainstalowany na pokładzie. Detekcja niestateczności musi polegać na pomiarze przyspieszenia wykonanym na ramie wózka.

\subsubsection{Monitorowanie stanu tożysk osi (p. 4.2.3.3.2)}

\section{- Pociagi klasy 1}

Stan maźnic w pociagach klasy 1 musi być monitorowany przez pokładowe urządzenia do wykrywania zagrzanych łożysk. Urządzenia te muszą być w stanie wykryć pogorszenie stanu maźnicy łożyskowej albo na podstawie pomiaru jej temperatury, częstotliwości procesów dynamicznych, albo na podstawie pewnych innych odpowiednich charakterystyk miarodajnych dla stanu łożyska.

System detekcji musi być zlokalizowany w całości na pokładzie.

- Pociagi klasy 2

Wyposażenie pociągów klasy 2 w pokładowe systemy detekcji nie jest wymagane, chyba że ich zagrzane maźnice łożyskowe nie mogą być wykryte przez przytorowe systemy detekcji.

\subsubsection{Uktad hamulcowy (p. 4.2.4.3)}

- Pociagi klasy 1 muszą być wyposażone w system monitorujący rotację kól, informujący maszynistę o zatarciu osi

- Pociagi o prędkości maksymalnej większej niż $200 \mathrm{~km} / \mathrm{h}$ należy wyposażyć w układ diagnostyki awarii układu hamulcowego.

\subsubsection{Wykrywanie wykolejeń (p. 4.2.3.4.11)}

Systemy wykrywania wykolejeń muszą być instalowane w nowych konstrukcjach zespołów trakcyjnych klasy 1, począwszy od chwili przyjęcia dotyczącej ich specyfikacji dla interoperacyjności i gdy będą dostępne na rynku. 
Dopóki specyfikacja dla interoperacyjności dotycząca systemów wykrywania wykolejeń nie zostanie udostępniona, dopóty instalowanie tych systemów nie będzie obowiązkowe.

\section{Wytyczne w zakresie realizacji diagnostyki ukladu biegowego dla pojazdów trakcyjnych modernizowanych i nowobudowanych}

Biorąc pod uwagę stan dotychczasowej diagnostyki na PKP, wymagania TSI oraz najnowsze tendencje w technice diagnostycznej należy prace ukierunkować na wprowadzenie diagnostyki pokładowej z wykorzystaniem możliwości obiektywnych metod prognozowania stanu technicznego pojazdu.

Ułatwieniem jest wprowadzenie mikroprocesorowych układów sterowania $\mathrm{w}$ pojazdach modernizowanych i nowobudowanych gdyż system ten jest łatwiej rozbudować o funkcje diagnostyczne. Konieczne jest stworzenie podstaw do opracowania własnych rozwiązań i wdrożenie ich przez polski przemysł.

Wykorzystując pracę [7] przyjmujemy, że w przypad$\mathrm{ku}$ oprogramowania pokładowego systemu diagnostyczno-sterującego, wykorzystującego optymalną prognozę należy zastosować:

- Procedury wyznaczania optymalnego zbioru parametrów diagnostycznych do opracowania $\mathrm{w}$ fazie projektowania i konstruowania pojazdu:

- liczby i miejsc rozmieszczenia punktów pomiarowych parametrów diagnostycznych układów lub zespołów pojazdu

- rodzaju monitorowania (tryb on line lub ofline) z użyciem czujników zainstalowanych na stałe $\mathrm{w}$ wyznaczonych punktach pomiarowych układów lub zespołów pojazdu w zależności od częstotliwości próbkowania, o której decyduje rodzaj parametrów i sposób jego pomiaru

- sposobu przetwarzania sygnałów wejściowych parametrów diagnostycznych

- oprogramowania użytkowego systemu w zakresie wyznaczenia optymalnego zbioru parametrów diagnostycznych

- Procedury określenia optymalnej metody prognozowania i wyznaczenia optymalnej prognozy do opracowania:

- programów użytkowych systemu w zakresie wyznaczenia optymalnej prognozy i archiwizacji informacji diagnostyczno-prognostycznej układów lub zespołów pojazdu

- adaptacyjnej strategii monitorowania umożliwiającej zmianę nastaw pomiarowych systemu (optymalny zbiór parametrów diagnostycznych, wartości progów alertowych i alarmowych, optymalna metoda prognozowania) w zależności od zmian stanu układu pojazdu (wymiana lub regulacja zespołu) oraz od zmian warunków eksploatacji pojazdu).
Ocenę stanu technicznego i prognozę należy wykonać poprzez jednoznaczne skojarzenie cech stanu obiektu ze zbiorem procesów wyjściowych czyli symptomów. Algorytmy przyporządkowujące sobie oba zbiory cech - konstrukcji i symptomów są podstawą tworzenia modeli diagnostycznych obiektów [4].

Model diagnostyczny obiektu jest to narzędzie pozwalające opisać obiekt i jego zachowanie $\mathrm{w}$ różnych warunkach za pomocą relacji diagnostycznej na zbiorze cech stanu i zbiorze symptomów.

Dla ułatwienia realizacji diagnostyki układu biegowego obiekt podzielimy na moduły stanowiące ograniczone zbiory właściwości obiektu wybrane decyzyjnie ze względu na cel badania.

\subsection{Miejsce zabudowy czujników monitorowania stanu wózka}

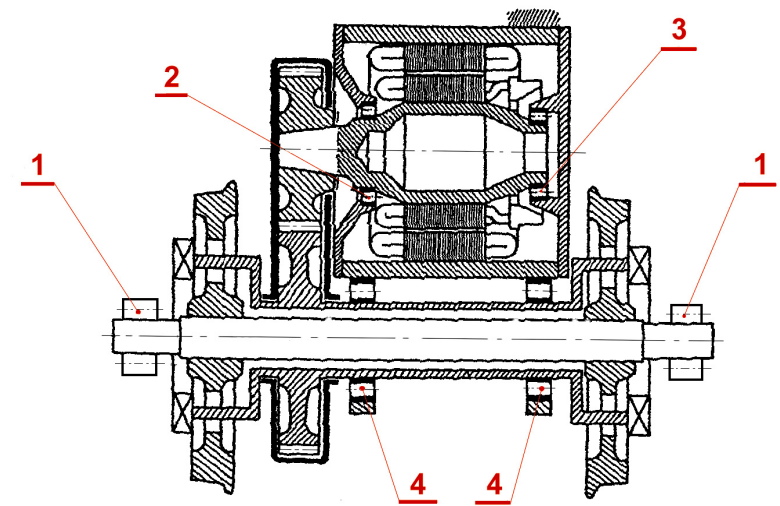

Rys. 5 - Schemat zabudowy czujników pomiarowych na układzie napędowym typu IEUsUpS [16] (np. lokom. EP07, EP08)

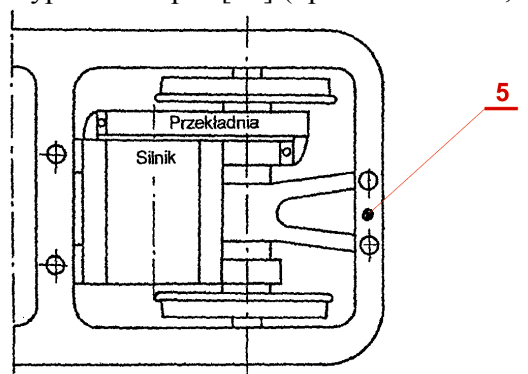

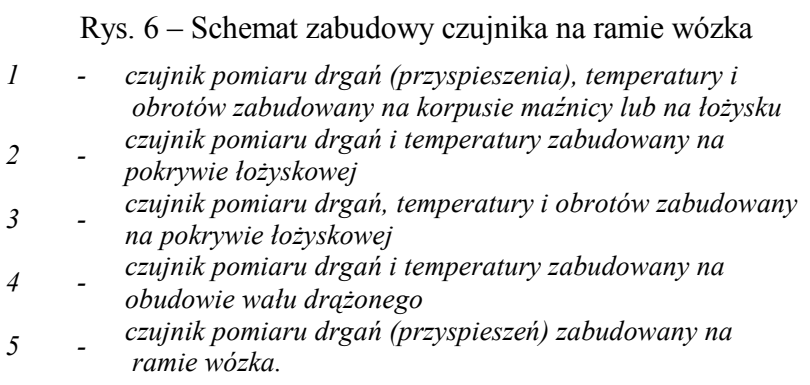

Na rys. 5 i 6 przedstawiono przykładowy schemat zabudowy czujników na wózku lokomotyw eksploatowanych na PKP.

Układ ten może być wykorzystany w całości lub ograniczyć się do zespołów czy podzespołów jak np. łożyskowanie zestawów kołowych czy łożyskowanie silnika trakcyjnego.

Mikroprocesorowy system powinien rozpoznawać automatycznie częstotliwości, które są charakterystyczne dla układów spowodowanych przez usterki. 


\subsection{Zestawienie modułów}

\begin{tabular}{|c|c|c|c|c|c|}
\hline L.p. & Moduł & Zadanie & Model & Symptom & Sygnat pomiarowy \\
\hline 1 & 2 & 3 & 4 & 5 & 6 \\
\hline 1. & $\begin{array}{l}\text { Modul 1: } \\
\text { Łożyska toczne maźni- } \\
\text { cy }\end{array}$ & $\begin{array}{l}\text { Monitorowanie stanu łożysk } \\
\text { Predykcja wystapienia uszko- } \\
\text { dzeń łożysk } \\
\text { Prognozowanie eksploatacji } \\
\text { łożysk }\end{array}$ & \multirow{2}{*}{$\begin{array}{l}\text { Symulacyjny model struk- } \\
\text { turalny pojazdu } \\
\text { uwzględniający: } \\
\text { - dynamikę pojazdu } \\
\text { - model kontaktu koło- } \\
\text { szyna } \\
\text { - model toru } \\
\text { (klasyczny model matema- } \\
\text { tyczny) }\end{array}$} & $\begin{array}{l}\text { Drgania węzła łoży- } \\
\text { skowego }\end{array}$ & \multirow[t]{2}{*}{$\begin{array}{l}\text { Mierzony na korpusie } \\
\text { maźnicy lub na łożysku } \\
\text { maźniczym: } \\
\text { - przyspieszenia } \\
\text { - częstotliwość drgań } \\
\text { (Czujnik poz. 1, rys. 5) }\end{array}$} \\
\hline 2. & $\begin{array}{l}\text { Modul 2: } \\
\text { Koło zestawu kołowe- } \\
\text { go }\end{array}$ & $\begin{array}{l}\text { Wykrycie i ocena wielkości } \\
\text { deformacji powierzchni tocznej } \\
\text { koła: } \\
\text { - płaskie miejsca } \\
\text { - nalepy } \\
\text { - owalizacja } \\
\text { Prognozowanie eksploatacji } \\
\text { kół }\end{array}$ & & $\begin{array}{l}\text { Drgania powstające na } \\
\text { styku koło-szyna }\end{array}$ & \\
\hline 3. & $\begin{array}{l}\text { Moduł 3: } \\
\text { Łożyska toczne maźni- } \\
\text { cy }\end{array}$ & $\begin{array}{l}\text { Monitorowanie temperatury } \\
\text { łożysk } \\
\text { Detekcja uszkodzenia }\end{array}$ & $\begin{array}{l}\text { Model symptomowy } \\
\text { (wykorzystujący diagno- } \\
\text { styczne symptomy stanu } \\
\text { technicznego) }\end{array}$ & $\begin{array}{l}\text { Wzrost temperatury } \\
\text { węzła łożyskowego }\end{array}$ & $\begin{array}{l}\text { Mierzony na korpusie } \\
\text { maźnicy lub na łożysku } \\
\text { maźniczym (czujnik } \\
\text { poz. } 1, \text { rys. 5) }\end{array}$ \\
\hline 4. & $\begin{array}{l}\text { Modul 4: } \\
\text { Łożyska toczne maźni- } \\
\text { cy }\end{array}$ & $\begin{array}{l}\text { Pomiar prędkości obrotowej } \\
\text { z przeznaczeniem do sterowa- } \\
\text { nia silnika trakcyjnego i układu } \\
\text { przeciwpoślizgowego }\end{array}$ & Model symptonowy & $\begin{array}{l}\text { Prędkość obrotowa } \\
\text { łożyska (osi) }\end{array}$ & $\begin{array}{l}\text { Mierzony w maźnicy lub } \\
\text { na łożysku maźniczym } \\
\text { (czujnik poz. 1, rys. 5) }\end{array}$ \\
\hline 5. & $\begin{array}{l}\text { Modul 5: } \\
\text { Łożyska toczne silnika } \\
\text { trakcyjnego strona } \\
\text { (przekładni) }\end{array}$ & $\begin{array}{l}\text { Monitorowanie stanu łożysk } \\
\text { Predykcja wystapienia uszko- } \\
\text { dzenia łożysk } \\
\text { Prognozowanie eksploatacji } \\
\text { łożysk }\end{array}$ & Model strukturalny & $\begin{array}{l}\text { Drgania węzła łoży- } \\
\text { skowego }\end{array}$ & $\begin{array}{l}\text { Mierzony na obudowie } \\
\text { łożyska: } \\
\text { - przyspieszenia } \\
\text { - częstotliwość drgań } \\
\text { (czujnik poz. } 2 \text {, rys. 5) }\end{array}$ \\
\hline 6. & $\begin{array}{l}\text { Modul 6: } \\
\text { Łożyska toczne silnika } \\
\text { trakcyjnego (strona } \\
\text { przekładni) }\end{array}$ & $\begin{array}{l}\text { Monitorowanie temperatury } \\
\text { łożysk } \\
\text { Detekcja uszkodzenia }\end{array}$ & Model symptomowy & $\begin{array}{l}\text { Wzrost temperatury } \\
\text { węzła łożyskowego }\end{array}$ & $\begin{array}{l}\text { Mierzony na obudowie } \\
\text { łożyska } \\
\text { (czujnik poz. } 2 \text {, rys. } 5 \text { ) }\end{array}$ \\
\hline 7. & $\begin{array}{l}\text { Moduł 7: } \\
\text { Łożyska toczne silnika } \\
\text { trakcyjnego (strona } \\
\text { przeciwna przekładni) }\end{array}$ & $\begin{array}{l}\text { Monitorowanie stanu łożysk } \\
\text { Predykcja wystapienia uszko- } \\
\text { dzenia łożyska } \\
\text { Prognozowanie eksploatacji } \\
\text { łożysk }\end{array}$ & Model strukturalny & $\begin{array}{l}\text { Drgania węzła łoży- } \\
\text { skowego }\end{array}$ & $\begin{array}{l}\text { Mierzony na obudowie } \\
\text { łożyska } \\
\text { - przyspieszenia } \\
\text { - częstotliwość drgań } \\
\text { (czujnik poz. } 3 \text {, rys. } 5 \text { ) }\end{array}$ \\
\hline 8. & $\begin{array}{l}\text { Modul 8: } \\
\text { Łożyska toczne silnika } \\
\text { trakcyjnego (strona } \\
\text { przeciwna przekładni) }\end{array}$ & $\begin{array}{l}\text { Monitorowanie temperatury } \\
\text { łożysk } \\
\text { Detekcja uszkodzenia }\end{array}$ & Model symptomowy & $\begin{array}{l}\text { Wzrost temperatury } \\
\text { węzła łożyskowego }\end{array}$ & $\begin{array}{l}\text { Mierzony na obudowie } \\
\text { łożyska } \\
\text { (czujnik poz. } 3 \text {, rys. } 5 \text { ) }\end{array}$ \\
\hline 9. & $\begin{array}{l}\text { Moduł 9: } \\
\text { Łożyska toczne silnika } \\
\text { trakcyjnego (strona } \\
\text { przeciwna przekładni) }\end{array}$ & $\begin{array}{l}\text { Pomiar prędkości obrotowej } \\
\text { silnika }\end{array}$ & Model symptomowy & $\begin{array}{l}\text { Prędkość obrotowa } \\
\text { łożyska (wału silnika } \\
\text { trakcyjnego) }\end{array}$ & $\begin{array}{l}\text { Mierzony na łożysku } \\
\text { (czujnik poz. 3, rys. 5) }\end{array}$ \\
\hline 10. & $\begin{array}{l}\text { Moduł 10: } \\
\text { Łożyska toczne wału } \\
\text { drążonego }\end{array}$ & $\begin{array}{l}\text { Monitorowanie stanu łożysk } \\
\text { Predykcja wystappienia łożyska } \\
\text { Prognozowanie eksploatacji } \\
\text { łożysk }\end{array}$ & Model struktoralny & $\begin{array}{l}\text { Drgania węzła łoży- } \\
\text { skowego }\end{array}$ & $\begin{array}{l}\text { Mierzony na obudowie } \\
\text { łożyska } \\
\text { (czujnik poz. } 4 \text {, rys. } 5 \text { ) }\end{array}$ \\
\hline 11. & $\begin{array}{l}\text { Modul 11: } \\
\text { Łożyska toczne wału } \\
\text { drążonego }\end{array}$ & $\begin{array}{l}\text { Monitorowanie temperatury } \\
\text { łożysk } \\
\text { Detekcja uszkodzenia }\end{array}$ & Model symptomowy & $\begin{array}{l}\text { Wzrost temperatury } \\
\text { węzła łożyskowego }\end{array}$ & $\begin{array}{l}\text { Mierzony na obudowie } \\
\text { łożyska: } \\
\text { (czujnik poz. } 4 \text {, rys. } 5 \text { ) }\end{array}$ \\
\hline 12. & $\begin{array}{l}\text { Modul 12: } \\
\text { Przekładnia }\end{array}$ & $\begin{array}{l}\text { Monitorowanie stanu prze- } \\
\text { kładni: } \\
\text { - uszkodzenia kół zębatych } \\
\text { - rezonanse }\end{array}$ & Model strukturalny & Drgania przekładni & $\begin{array}{l}\text { Mierzony na obudowie } \\
\text { łożyska: } \\
\text { - przyspieszenia } \\
\text { - częstotliwość drgań } \\
\text { (czujnik poz. } 2 \text {, rys. 5) }\end{array}$ \\
\hline 13. & $\begin{array}{l}\text { Modul 13: } \\
\text { Niestabilność wózka }\end{array}$ & $\begin{array}{l}\text { Wykrywanie niestabilności } \\
\text { wózka }\end{array}$ & Model strukturalny & $\begin{array}{l}\text { Niestateczność wózka - } \\
\text { wzrost przyspieszeń na } \\
\text { ramie wózka }\end{array}$ & $\begin{array}{l}\text { Mierzony na ramie } \\
\text { wózka - przyspieszenia } \\
\text { (czujnik poz. } 5 \text {, rys. } 6 \text { ) }\end{array}$ \\
\hline
\end{tabular}

Zestawienie modułów jest przykładowym rozwiązaniem diagnostyki dla danego typu pojazdu. Budowa modułowa pozwala na wybór zakresu realizacji np. stan łożyska możemy ocenić poprzez pomiar temperatury lub poprzez pomiar drgań.

W naszym przypadku zaproponowano diagnostykę przekładni poprzez pomiar drgań na łożysku. Wynika to $\mathrm{z}$ konstrukcji przekładni gdyż obudowę stanowi osłona wykonana $\mathrm{z}$ blachy.

Analiza częstotliwościowa (widmowa) drgań węzła łożyskowego polegająca na rozłożeniu sygnału drganiowego na składowe harmoniczne o określonych częstotliwościach odpowiadających danym uszkodzeniom daje nam niezbędne informacje o stanie prze- 


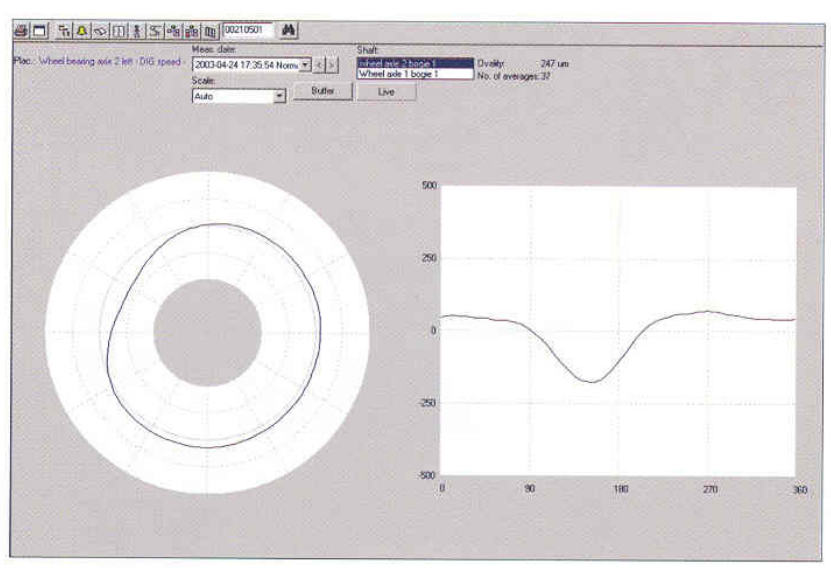

Rys. 7 - Zmiana kształtu koła [1]

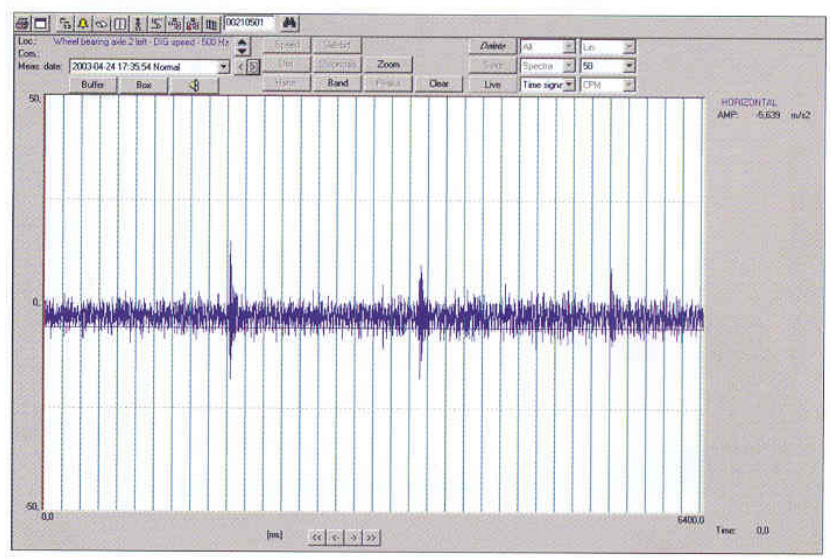

Rys. 8 - Widmo drgań koła ze zmienionym kształtem wg rys. 7 [1]

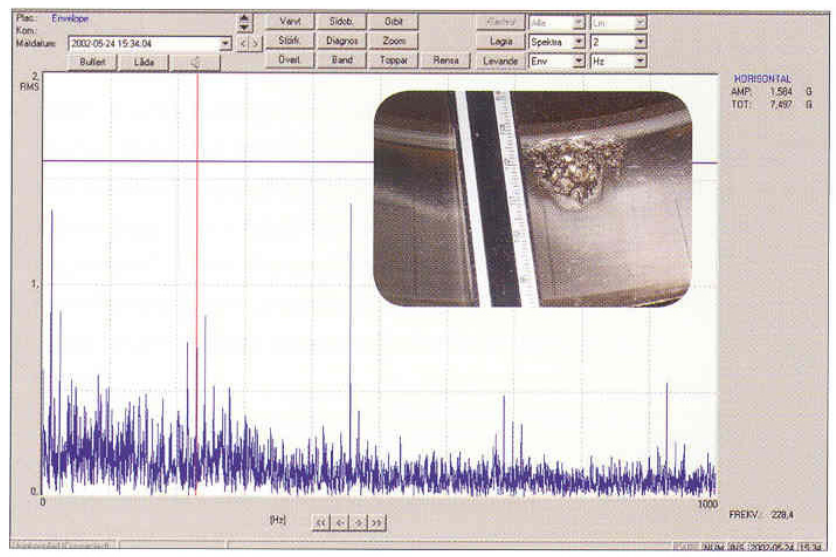

Rys. 9 - Widmo drgań maźnicy z uszkodzonym łożyskiem [1]

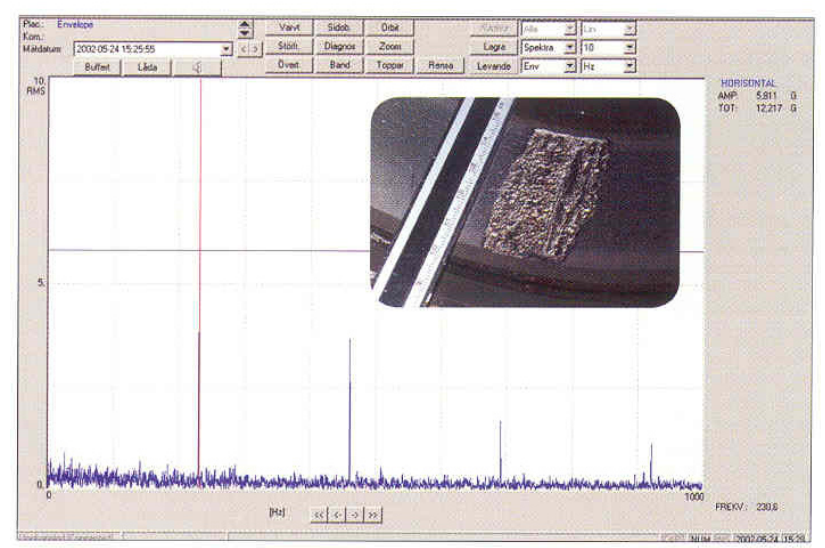

Rys. 10 - Widmo drgań maźnicy z uszkodzonym łożyskiem [1]

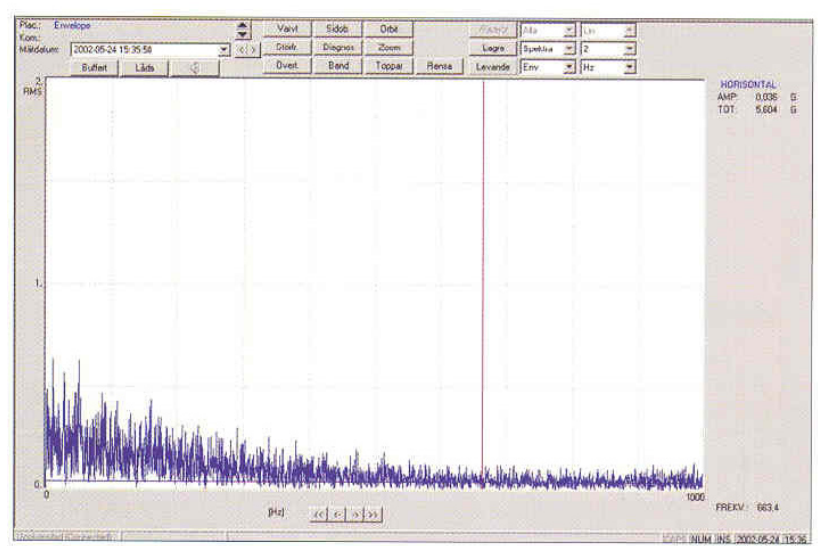

Rys. 11 - Widmo drgań maźnicy z dobrymi łożyskami [1]

kładni i łożyskowania.

Przykładową analizę widmową drgań węzła łożyskowego maźnicy przedstawiająca uszkodzenia koła i łożyska przedstawił SKF w swojej publikacji [1].

Prognozę możemy wykonać badając ewolucję określonej miary (symptomu) przy zmiennym czasie eksploatacji. Tzw. krzywa eksploatacyjna będzie identyfikować rodzaj uszkodzenia i jego zachowanie.

Wnioskowanie diagnostyczne winno być oparte na określeniu trendu symptomu czy też przy wykorzystaniu specjalnych metod badania trendów.

Korzystając z literatury [2] przedstawiono na rys. 12 graficzne prognozowanie wg znanego modelu trendu.

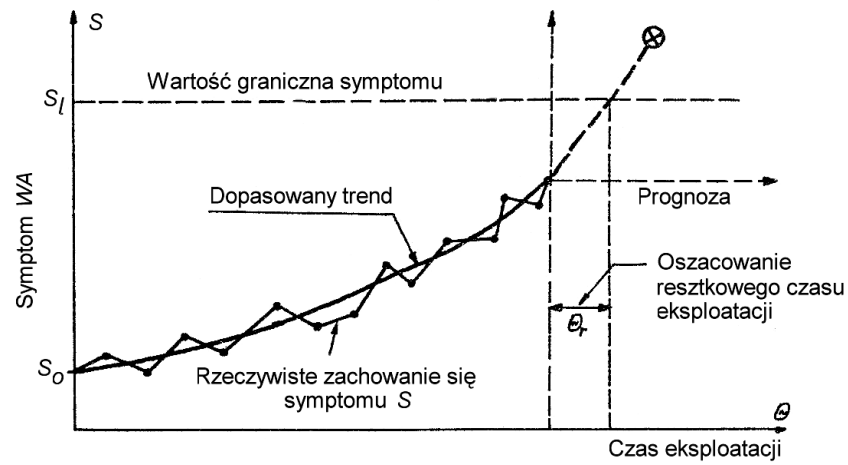

Rys. 12 - Ilustracje prognozowania resztkowego czasu eksploatacji wg znanego modelu trendu

\section{Podsumowanie}

Ze względu na ograniczone ramy artykułu problemy związane z rozwiązaniem diagnostyki układu biegowego pojazdu zostały przedstawione $\mathrm{w}$ formie wytycznych do realizacji diagnostyki pokładowej i ograniczone do przedstawienia modułów diagnostycznych. Moduły modelu muszą być opracowane dla konkretnego pojazdu i uszkodzenia.

\section{Literatura}

[1] SKF: Railway technical handbook, Axleboxes, wheelset bearings, sensors, condition monitoring, subsystem and services.

PUB 42/P7 1098 EN-September 2010. 
[2] Czesław Cempel: Podstawy wibroakustycznej diagnostyki maszyn. WN-T 1982.

[3] Józef Marciniak: Diagnostyka techniczna kolejowych pojazdów szynowych. WKit Warszawa 1982.

[4] Bogdan Żóltowski: Podstawy Diagnostyki Maszyn Wydawnictwo ATR, Bydgoszcz 1996.

[5] Tomasz Kucharski: System pomiaru drgań mechanicznych WNT, Warszawa 2002.

[6] M. Hebda, S. Niziński, H. Pelc: Podstawy diagnostyki pojazdów mechanicznych. WKit Warszawa 1982.

[7] Henryk Tylicki: Optymalizacja procesu prognozowania stanu technicznego pojazdów mechanicznych. Rozprawa nr 8, ATR Bydgoszcz 1998.

[8] Wytyczne techniczno-eksploatacyjne urzadzeń do wykrywania stanów awaryjnych taboru Je-3 PKP PLK S.A., Warszawa 2005.

[9] Peter Meinke: Laufzustands - und Streckenbewertung mit Entgleisungsdetektion. ETR - Eisenbahn techn. - Rundsch. - 2007 nr 5.
[10] Thiele M. Siegenthaler R. Sjoberg R.: Mechanische Drehgestellueberwachung mit Datenfemzugriff. ZEV - Glas. Ann. 2004 nr 11/12.

[11] TSI - Decyzja Komisji Europejskiej $n r$ 2008/232/WE.

[12] System diagnostyczny kót kolejowych ARGUS Materiaty reklamowe firmy HEGENSCHEIDT MFD (Niemcy).

[13] Systemy wykrywania stanów awaryjnych taboru kolejowego podczas jazdy ASDEK - Materiaty reklamowe firmy TENS Sp. z o.o. w Sopocie.

[14] Laserowe systemy pomiarowe GRAW - Materiaty reklamowe P.U.-T sp. z o.o. Gliwice.

[15] Komputerowe systemy diagnostyki taboru kolejowego TENSAN - Materiaty reklamowe firmy TENS sp. z o.o. w Sopocie.

[16] Jerzy Madej: Mechanika napędu pojazdów szynowych z elektrycznymi silnikami trakcyjnymi. PWN, Warszawa 1983. 